\title{
ANTIOXIDANTS AND GENE REGULATION: \\ The Effects of Vitamins $C$ and E on Estrogen Receptors
}

JEONG HO NAM

RESEARCH SHOWS THAT ESTROGEN BINDING TO ITS RECEPTOR PLAYS A ROLE IN BREAST CANCER DEVELOPMENT AND THAT ANTIOXIDANTS POSSIBLY MITIGATE THIS EFFECT. PAST RESEARCH EXAMINED WHETHER VARIOUS TREATMENTS LEAD TO ACCELERATED CELL DIVISION, BUT CHARACTERIZATION AND COMPARISON OF THE EFFECTS OF DIFFERENT TREATMENTS ON GENE LEVEL EXPRESSION OF THE RECEPTOR WAS NOT ACCOMPLISHED. INITIALLY, THE EFFECT OF ANTIOXIDANTS ON THE ESTROGEN RECEPTOR EXPRESSION WAS INVESTIGATED, REVEALING THE PRESENCE OF VITAMINS C AND E. SUBSEQUENTLY, THE INDIVIDUALEFFECTS OF VITAMINSCANDE ON NITRIC OXIDE RELEASE (A POSSIBLE CANCER REDUCTION AGENT) STIMULATED BY ESTROGENACTING ON THE SURFACE ESTROGEN RECEPTOR OF BREAST CANCER CELLS WAS OBSERVED. GENERALLY, VITAMIN E WAS MOST EFFECTIVE FOR IMPROVING NITRIC OXIDERELEASE. 


\section{INTRODUCTION}

Breast cancer is one of the most common cancers among women worldwide. Statistical data have shown that among American women, nearly one out of three cancers diagnosed is a breast cancer and in the year 200I, approximately 192,200 cases of breast cancer were diagnosed among women in the United States. Through many years of breast cancer research, it has been documented that estrogen plays a critical role in the development of breast cancer. $^{\mathrm{i}}$

Estrogens are steroid molecules and sex hormones that stimulate the development of female characteristics and sexual reproduction. The most common forms of human estrogens are I7-beta estradiol and estrone that are produced and secreted by the ovaries. Two of the female organs that play a central role in sexual reproduction, the breast and the uterus, are the main target organs of the estrogen molecule. Cells of the breast and the uterus have estrogen receptors (alpha and beta) that have specific sites to which only estrogen can bind. Estrogen molecules are only effective when they bind to the receptors. When estrogen molecules pass through the membrane of the cell and bind to the estrogen receptors, the shape of the receptor changes and estrogen receptor complex attaches to the estrogen response elements (EREs) in DNA, causing certain genes to become active. The active genes produce molecules of messenger RNA that influence cell activity in a variety of ways by synthesizing specific proteins. ${ }^{\text {ii }}$ This study examines the interaction of estrogen and antioxidants on the expression of estrogen receptor genes.

Cancer is caused by mutations in growth regulatory genes. Mutations may be caused by transcription errors in DNA before the process of cell division. ${ }^{\text {iii }}$ As these cells proliferate, the transcription errors are then carried on to the new generation of cells and may lead to uncontrollable proliferation.

Besides its role in developing female sexual characteristics, estrogen also impacts on the health of the immune system, and the body's response to the stress and the changing environment. ${ }^{\text {iv }}$ One of the main effects of estrogen is inducing stimulation for cell proliferation. Cell proliferation is estrogen's natural role but it increases a woman's chance of developing breast cancer or uterine cancer. Previous studies have demonstrated the effect of $\mathrm{I} 7$-beta estradiol on cell proliferation. In several studies, r7-beta estradiol enhanced the rate of cell proliferation and also decreased the level of apoptosis of breast cancer cells by inducing the bcl-2, antiapoptosis gene . vi Estrogen cannot distinguish between mutated cells and healthy cells. Proliferation stimulated by estrogen can result in the proliferation of mutant cells, thereby causing cancer. ${ }^{\mathrm{vii}}$ To prevent estrogen from promoting cell proliferation, researchers have been developing anti-estrogen substances such as tamoxifen, and raloxifene that can block the estrogen receptor. ${ }^{\text {vii }}$

Currently, two types of estrogen receptors (ER) have been identified, alpha and beta. They both bind to DNA but it has been shown that in MCF-7 adenocarcinoma human breast cancer cells, ER alpha is the prevalent form and ER beta is hardly detectable. Estrogen alpha-receptor is also mainly involved with the development of a breast cancer. ${ }^{\text {ix }}$

Most research on breast cancer regarding antioxidants has focused on the effect of melatonin (pineal indoleamine), a type of an antioxidant, on the proliferation of MCF-7 breast cancer cells. Various studies have demonstrated that melatonin has an anti-proliferative effect on estrogen responsive MCF-7 breast cancer cells and also that the administration of melatonin reduces the incidence and growth rate of chemically induced mammary tumors. ${ }^{x}$ According to the several studies, not only does melatonin inhibit the MCF-7 cell growth but it also increases cell doubling time and delays the entry of MCF-7 cells into mitosis. ${ }^{x i}$ Furthermore, it has been shown that melatonin decreases ER bonding activity and ER mRNA expression. xii However, when melatonin and estradiol were treated together, the anti-proliferative effect of melatonin was reversed, demonstrating that the effect of melatonin can be counteracted by cell cycle acceleration stimulated by estradiol. xiii 
NO-specific amperometric probe.

In addition, the effects of other types of antioxidants such as carotenoids, and retinoic acid on MCF-7 cell growth also have been widely studied. These antioxidants have been shown to have an inhibitory effect on the ER positive MCF7 cell growth but not on ER negative MDA-MB-23I breast cancer cells. ${ }^{\text {xiv }}$ On the other hand, it has been reported that vitamin $\mathrm{E}$, selenium, and palm oil tocotrienols have been shown to be effective anti-proliferative agents in both ER negative and positive cells breast cancer cells. ${ }^{\mathrm{xV}}$ Unlike previous studies where researchers observed the effect of antioxidants on the proliferation of the cells, in the first part of this study, the effect of the antioxidants ascorbic acid (vita$\min$ C) and alpha tocopheral (vitamin E) on the gene expression of estrogen receptor will be observed.

Another part of this study is to investigate whether ascorbic acid and alpha tocopherol can affect the nitric oxide release from the surface receptor of ER positive MCF-7 cells. Several studies have found the existence of surface estrogen receptors in human peripheral monocytes and the ganglionic nervous system of Mytilus edulis, the common mussel. These investigations also demonstrated that I7beta estradiol stimulates nitric oxide (NO) release by binding to the cell surface estrogen receptor. ${ }^{\text {vi }}$ Nitric oxide is a free radical that scavenges other free radicals and controls the activation state of various tissues such as immune cells, thereby helping to maintain appropriate levels of cellular activity. NO has also been shown to play a host defense against tumors, viruses and bacteria. In addition, it has been shown that free radicals promote cancer by damaging DNA. Since NO release is one of estrogen receptors' critical functions, investigating the effect of antioxidants on NO release by surface estrogen receptors on MCF-7 cells is essential. However, it has been found out that while NO plays an important role in numerous physiological and pathophysiological conditions, excessive concentrations of NO may lead to a tissue damage and organ dysfunction. ${ }^{\text {xvii }}$ In the second phase of this experiment, cells are pre-treated with ascorbic acid and alpha tocopherol, and then the NO release triggered by 17 -beta estradiol is measured by using

\section{MATERIALS AND METHODS}

\section{GENE EXPRESSION}

\section{CELL CULTURING}

A flask with MCF-7 cells (American Type Culture Collection, ATCC), RPMI I640 Io percent Media (GIBCO, Invitrogen, Carlsbad, CA) and Tripsin (SIGMA, St Louis, $\mathrm{MO}$ ) were prepared. From the original flask with MCF-7 cells, the media was removed, and then washed with $2 \mathrm{ml}$ of trypsin. Three $\mathrm{ml}$ of trypsin was added to the flask containing MCF-7 cells, and the flask was tilted back and forth so the trypsin would cover the whole surface with MCF-7 cells. The flask was then sat still for 5 to 15 minutes until all the cells detach from the flask surface. When all the cells were detached, $7 \mathrm{ml}$ of media was added to neutralize the Tripsin. Remaining cells were rinsed with phosphate buffered saline (PBS) by using a pipet. Everything in the flask was transferred to a $15 \mathrm{ml}$ tube and then centrifuged for $3 \mathrm{~min}$ utes at $1000 \mathrm{rpm}$. After the tube was centrifuged, the liquid in the tube was decanted. The cell pellet in the tube was then resuspended by adding Ioml of RPMI media. The cell pellet and the media were pipetted up and down until cell pellet was completely broken. I X Io6 cells was added to each well of two six wells plates in $2 \mathrm{ml}$ RPMI media and then incubated in a $37 \mathrm{oC}$ incubator.

\section{PREPARING SOLUTIONS}

Ascorbic acid (vitamin C) stock solution with iM concentration was prepared by adding $0.18 \mathrm{~g}$ of Ascorbic acid (SIGMA, St Louis, MO) to Iml of PBS (Phosphate Buffer Saline) (GIBCO, Invitrogen, Carlsbad, CA), and then roÌl was added to 99oul of PBS, to make IomM solution.

Alpha tocopherol solution (vitamin E) (SIGMA, St Louis $\mathrm{MO}$ ) was prepared next. IM stock solution was made by adding $0.43 \mathrm{~g}$ to $\mathrm{Iml}$ of ethanol. 50 Ìl from theiM stock solution was added to 950 Ill of ethanol for concentration of $50 \mathrm{mM}$. Again roÌl of the solution was added to goÌl of PBS for concentration of $5 \mathrm{mM}$. 
Estrogen solution was also prepared. I0-3 M stock solution was prepared by adding $0.003 \mathrm{~g}$ of I7-, estradiol (SIGMA, St Louis $\mathrm{MO}$ ) to Ioml of ethanol. IoIl of the solution was then added to 990 IIl PBS for concentration of IO-5 M.

\section{CELL TREATMENT}

Two six wells plates were treated in the following order. First two wells were untreated as controls. Next two wells were treated with Ascorbic acid. 20 İl of IomM Ascorbic acid solution was added to these wells for final concentration of IooÌM for each well. Same procedure was repeated for next two wells but I7-beta estradiol solution was added with Ascorbic acid. 20 Ill of the IO-5 M I7-beta estradiol solution was added the wells for final concentration of $10-7 \mathrm{M}$ along with 20 Ìl of IomM Ascorbic acid solution.

After treating first plate, second plate was treated with combinations with alpha tocopherol solution. First two wells were treated with alpha tocopherol solution. $20 \mathrm{l} 1$ of $5 \mathrm{mM}$ alpha tocopherol solution was added to the well for a final concentration was 50 ÌM for each well. Next two wells were treated with combination of alpha tocopherol and I7-beta estradiol solution. Again 2 ò̀l of $5 \mathrm{mM}$ alpha tocopherol solution was added to the two wells and then 20 Ill of the 10-5 M I7-beta estradiol solution was added. For last two wells, Ascorbic acid and alpha tocopherol solutions were added together. 2011 of IomM Ascorbic acid solution was added, and then 20 İl of $5 \mathrm{mM}$ alpha tocopherol solution was added. These plates were incubated for 24 hours at 39 degrees Celcius.

\section{RNA ISOLATION USING RNEASY(R) PROTECT} MINIKIT(250) (QIAGEN)

After $24 \mathrm{hr}$. incubation, each type of cells was collected into I $5 \mathrm{ml}$ Falcon tubes using sterile cell scraper. Tubes were then centrifuged for five minutes at 300-x g. After centrifuge was done, supernatant from each tube was discarded, and then 600 İl of Buffer RLT was added to each tube to disrupt the cells. When Buffer RLT was added to the tube, it was pipetted up and down several times for homog. enization. After that, Gooll of 70 percent ethanol was added to the homogenized lysate of each tube and mixed well by pipetting. $700 \mathrm{ll}$ of each sample was added to RNeasy mini spin column sitting in a $2-\mathrm{ml}$ collection tube (supplied), and centrifuged for I5 seconds at I0,000 rpm. Volume of the each sample exceeded 7ooİl, so flowthrough of the collection tube was discarded and then rest of the aliquots were added to the same RNeasy column and the each column was centrifuged again. After the centrifuge, flow-through was discarded. 70oÌl of Buffer RWI was pipetted onto each of RNeasy column, and columns were centrifuged for I5 seconds at I0,000 for washing. After that flow-through and collection tubes were discarded. RNeasy column were transferred into a new 2-ml collection tube (supplied). 500 Ìl of Buffer RPE were pipetted onto the each column, and the columns were centrifuged for two minutes at maximum speed to dry the RNeasy membrane. After the centrifuge was done, RNeasy spin column were placed in a new two-ml collection tube, which were not supplied and old collection tube with filtrate was discarded. RNeasy spin column with new collection tubes were centrifuged at full speed for I minute. After this step was completed, each RNeasy column was transferred into a new I.5-ml collection tube (supplied), and 30 İl of RNase-free water was directly added to the each of RNeasy column. Columns were centrifuged for one minute at ro, 0o orpm as for final step in collecting mRNA. mRNA from each sample was collected into the tube and the columns were discarded. mRNA sample tubes were immediately placed on ice.

RT (REVERSE TRANSCRIPTION)

Optical Density was first founded for each sample of mRNA, for the calculation for making the concentrations of RNA samples to be equal. RNA samples were diluted in RNase-free water in a new $200 I 1$ tubes. These samples were then denatured at 95 degrees Celcius for one minute. After the denaturation step, to the each tube, following reagents (All from Invitrogen ${ }^{\mathrm{TM}}$, Carlsbad, CA) were added: 8 Ìl of dNTP's, 4 Ìl of 5 X Ist Strand Buffer, 2 İl of O.I M DTT, ìll of Random Primer, IÌl Rnase Inhibitor (SIGMA, St Louis, MO). After reagents were added, Iİl of enzyme, 
Super Script ${ }^{\mathrm{TM}}$ II RNase H-Reverse Transcriptase (Invitrogen ${ }^{\mathrm{TM}}$, Carlsbad, CA) was added to the each sample. Samples were ran in Thermal Cycler (Gene Amp PCR System 9700, Applied Biosystem) for 60 minutes at $40^{\circ} \mathrm{C}$, and then ro minutes at $65^{\circ} \mathrm{C}$. After RT was done samples were placed in ice.

PCR (Polymerase Chain Reaction)

To the $200 \mathrm{Il}$ tubes prepared for the cDNA (RT products), following components (Invitrogen ${ }^{\mathrm{TM}}$, Carlsbad, CA) were added for PCR: 5 İl of IoX PCR buffer, I.5Ìl of Magnesium Chloride, 2Ìl of dNTP's, Iİl of Estrogen --receptor forward primer, IÌl reverse primer, 29 Ìl of Rnase free water, IoÌl of cDNA. In addition, primers specific for the,-actin gene was also used as an internal control for the PCR reaction.

Sequence of Forward and Reverse Estrogen Alpha Primer: Forward Primer: 5'-ATCCTGATGATTGGTCTCGTCT-3' Reverse Primer: 5'-GGATATGGTCCT'TCTCTTCCAGA-3'

Sequence of Forward and Reverse Estrogen Beta Primer: Forward Primer: 5'-GCTCATCTTTGCTCCAGATCTTG-3' Reverse Primer: 5'-CAATCACCCAAACCAAAGCATC-3' The samples were denatured at $95^{\circ} \mathrm{C}$ for 2 minute in a thermal cycler (Gene Amp PCR System 9700, Applied Biosystem), and then added 0.5ll of Taq DNA polymerase to each tube. The PCR analysis was performed for 35 cycles at $95^{\circ} \mathrm{C}$ for $30 \mathrm{sec}, 55^{\circ} \mathrm{C}$ for $30 \mathrm{sec}, 72^{\circ} \mathrm{C}$ for I min, then as a final primer extension step, $72^{\circ} \mathrm{C}$ for Io minutes. The PCR product was analyzed by gel electrophoresis.

\section{ELECTROPHORESIS}

Ig of Agarose was added to a flask then $60 \mathrm{ml}$ of IX TBE Buffer solution were added. The flask was then microwaved for about 2 minutes until the solution started boil. After the solution cooled down, sill of Ethidium Bromide was added and mixed well. The gel was then cast onto a horizontal gel electrophoresis apparatus. 45 İl of each PCR product was mix with gìl of DNA loading buffer, and 30 Ìl from the mixture was loaded onto the gel. After electrophoresis, the gel was visualized and analyzed by a
Gel Documentation system (UVP) containing an ultraviolet transilluminator.

\section{NITRIC OXIDE DETERMINATION}

\section{CELL CULTURING}

Same step was performed as for gene expression except that nitric oxide determination was done to the cells in 96 wells plates, so 200 ìl from mixture of cells and media were pipetted to the each well. This step was done to I5 wells.

\section{CELL TREATMENT}

First five wells were left as control. To next five wells, 2İl of Ascorbic acid (Vitamin C) solution with concentration of IomM was added for the final concentration of IooÌl for each well. To last five wells, zìl of Alpha tocopherol (Vitamin E) solution with concentration of $5 \mathrm{mM}$ was added to each well for the final concentration of $50 \mathrm{IM}$. Pre-treated cells were incubated for 24 hours at 39 degrees Celcius.

\section{NITRIC OXIDE DETERMINATION}

For Nitric Oxide detection, Apollo 4000 Free Radical Analyzer manufactured by World Precision Instrument (Sarasota, FL) was used. NO release was detected with an NO-selective microprobe manufactured also by World Precision Instruments (Sarasota, FL). The redox current was detected by a current-voltage converter circuit and continuously recorded. The dimensions of the probe (30 İM diameter, $0.5 \mathrm{~mm}$ length) permitted the use of a micromanipulator (Zeiss-Eppendorff). The sensor was placed approximately Ioo İM above the respective tissue surface. Calibration of the electrochemical sensor was performed by use of different concentrations (IoÌl, 2oÌl, 4oÌl, and 8oìl) of a nitrosothiol donor S-nitroso-N-acetyl-DL-penicillamine (SNAP). Each well was placed under the probe and the graph was observed by the computer interfaced DUOI8 software (World Precision Instruments, Sarasota, FL). When the graph line stabilized, IoÌl of I7-, estradiol solution with concentration of IO-5 M was added to the well to stimulate NO release. Amount of NO release was graphed on the monitor and it was measured. 


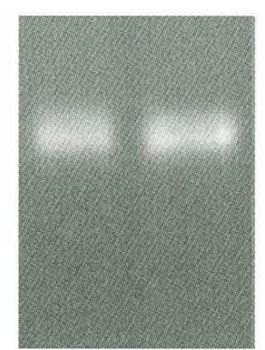

FIGURE 1A

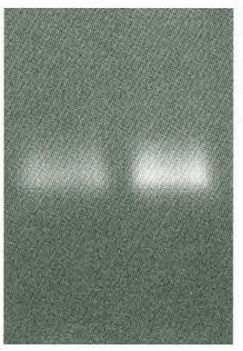

FIGURE 2A

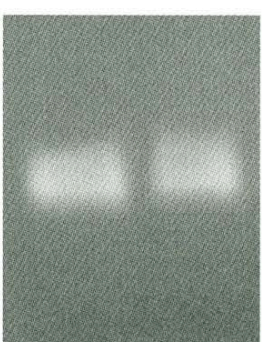

FIGURE 1 B

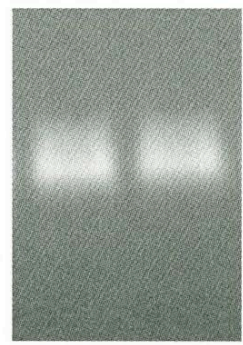

FIGURE 2B

\section{GENE EXPRESSION FOR ESTROGEN ALPHA RECEPTORS IN MCF-7 CELLS}

Figure IA: The band in the left lane represents the amplified cDNA of ER-alpha genes in MCF-7 cells that were treated with I7-beta estradiol. The band on the right lane is that of control group of untreated cells. The brightness of the band on the right lane (control group) is slightly brighter than brightness of the band on the left lane (I7-beta) estradiol, suggesting that I7-beta, estradiol slightly down-regulated the gene expression.

Figure IB: Expression levels for beta-actin primer remained constant for two samples in Figure IA, which verified equivalent sample loading.

Figure 2A: The band on the left represents the amplified cDNA of ER-alpha genes in a group of MCF-7 cells that were treated only with ascorbic acid, and the band on the right lane represents amplified cDNA(ER-alpha) of the group treated in a combination of I7-beta estradiol and ascorbic acid. The brightness of the band on the right lane (a group treated with the combination) is shown to be brighter than the brightness of the band in the left lane (a group treated with ascorbic acid), which means that more cDNA was amplified in the group treated with the combination. Also when the two bands in Figure $2 \mathrm{~A}$ are compared to the control band in Figure IA, the control group of Figure $\mathrm{I}$ is brighter than the left lane of Figure 2 (ascorbic acid) but dimmer than the right lane of Figure $2 \mathrm{~A}$ (I7-beta estradiol and ascorbic acid). This indicates that ascorbic acid alone resulted in a down-regulation (less cDNA were amplified) of ER-alpha gene expression and the combination of ascorbic acid and I7-beta estradiol resulted in an up-regulation.

Figure 2B: Expression levels for beta-actin primer remained constant for two samples in Figure $2 \mathrm{~A}$, which verified equivalent sample loading. 


\section{GENE EXPRESSION}

PCR products were analyzed on a two percent Agarose gel and a gel documentation system containing a UV transilluminator (UVP) (Figure I-4). Brightness of the bands from the results of beta-actin gene expressions (Figure IB, 2B, $\left.{ }_{5} \mathrm{~B}\right)$ verified equivalent sample loading. Figures $\mathrm{IA}$ and $2 \mathrm{~A}$ below show bands that represent the amplified amount of cDNA for ER-alpha genes. The brighter the band is, the more amplified cDNA is present. Since the cDNA was generated by a Reverse Transcription of mRNA, the brighter the band, the greater level of the expression of the ER-alpha gene that produced the mRNA. The right lane in Figure IA shows the bands of amplified cDNA of a control group of untreated MCF-7 cells (right lane), and the experimental group treated with I7-beta estradiol (left lane). A slight difference in the brightness of the two bands can be noticed. It appears that the control group band is brighter than the 17-beta estradiol treated group, which means that the ERalpha gene had diminished expression in the group treated with estradiol. In other words I7-beta estradiol appears to have down-regulated the gene. Figure $2 \mathrm{~A}$ shows the band of the group treated with ascorbic acid (left lane), and the band of the group treated with the combination of ascorbic acid and I7-beta estradiol (right lane). When the left lane in Figure $2 \mathrm{~A}$ (ascorbic acid treatment) is compared to the right lane of Figure IA (control), the control again appears brighter, suggesting that ascorbic acid also down-regulates the expression of the ER-alpha gene. The right lane (ascorbic acid and I7-beta estradiol treated) is brighter than both the left lane (ascorbic acid treatment) of Figure $2 \mathrm{~A}$ and the right lane (control) of Figure IA, suggesting that when ascorbic acid is in a combination with estrogen, it can upregulate the ER-alpha gene.

In the RT-PCR for estrogen-beta receptors, it was difficult to compare the expression levels because the bands (shown in Figures 3, and 4) were so faint. A possible explanation for such a low expression level might be because in MCF-7 cells, the alpha-receptor is the prevalent form and the betareceptor is hardly detectable. xviii

It appears that the anti-proliferative effect of ascorbic acid on MCF-7 cells reported in the literature ${ }^{x i x}$ is related to the down-regulation of estrogen receptor gene expression in MCF-7 cells treated with ascorbic acid. There was also a slight down-regulation in the gene expression level in the group treated with I7-beta estradiol and it seems that this down regulation was caused by a negative feedback due to the addition of $\mathrm{r} 7$-beta estradiol.

Previous work found that when estrogen is added to the melatonin, an antioxidant, the anti-proliferative effect of melatonin was reversed. Similarly in this research, it appears that the down-regulating effect on the ER alpha-re-

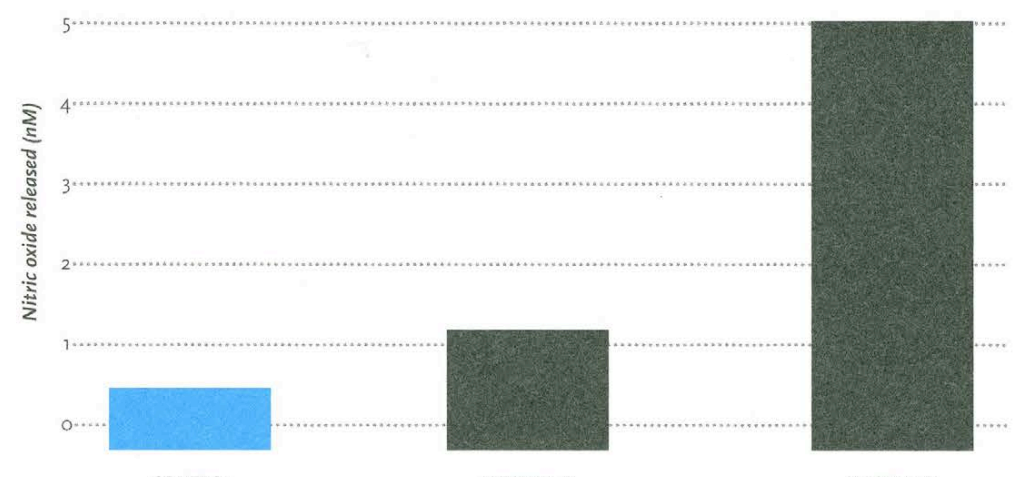

CONTROL
VITAMIN C
VITAMIN E

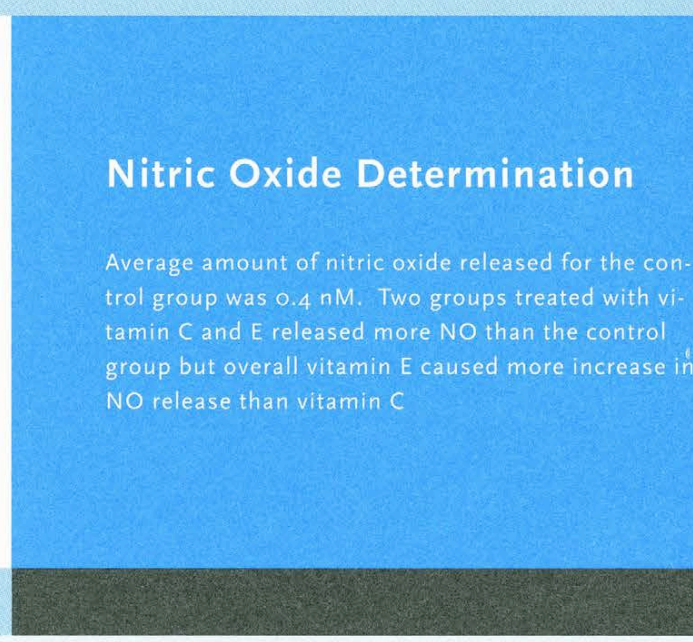




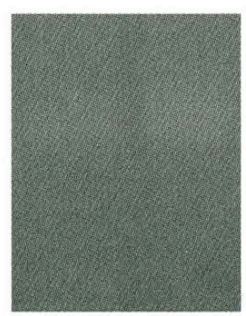

FIGURE 3

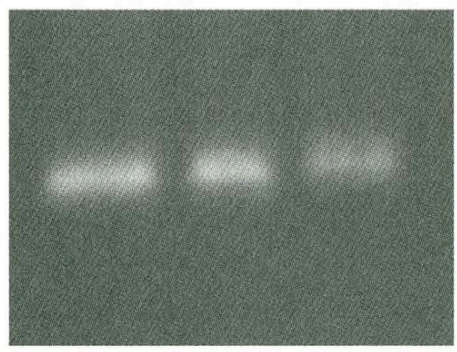

FIGURE 5B

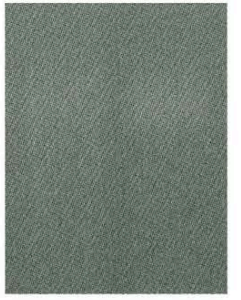

FIGURE 4

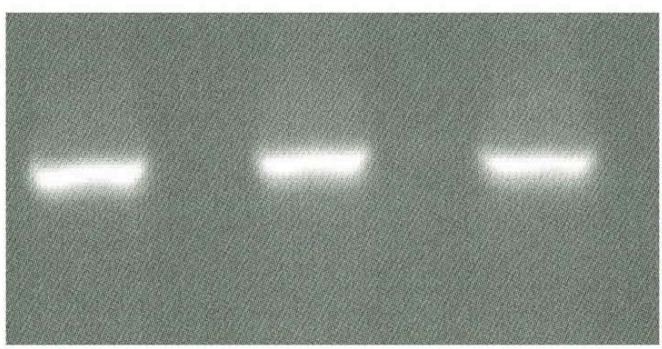

FIGURE $5 B$

\section{Gene Expression FOR ESTROGEN BETA RECEPTORS IN MCF-7 CelLS}

Figures 3 and 4: Possibly due to the fact that estrogen alpha-receptors are the prevalent form in MCF-7 cells and that beta-receptors are hardly detectable, a minimal amount of cDNA for beta receptors were amplified. This caused the brightness of the bands visualized on the gel to be very faint. No conclusions could be drawn.

\section{GENEEXPRESSION FOR ESTROGEN ALPHA RECEPTORS IN MCF-7 CELLS}

Figure 5A: From left: control group (untreated), alpha tocopheral (vitamin E) treated group, and the group treated in a combination of I7beta estradiol and alpha tocopheral. No significant difference in the brightness of the bands of control group and vitamin $\mathrm{E}$ treated group could be found, but when third band (vitamin E and I7-beta estradiol) is compared to other two bands, the third band is less bright. The combination of alpha tocopheral and estrogen appears to have down-regulated ER-alpha gene expression level.

Figure 5B: Expression levels for beta-actin primer remained constant for all three samples, which verified equivalent sample loading. 


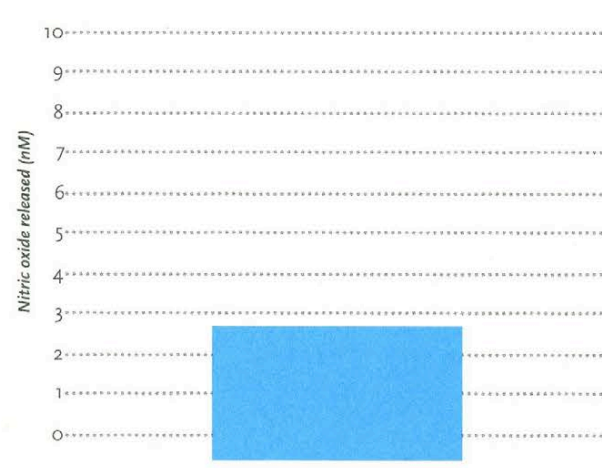

CONTROL

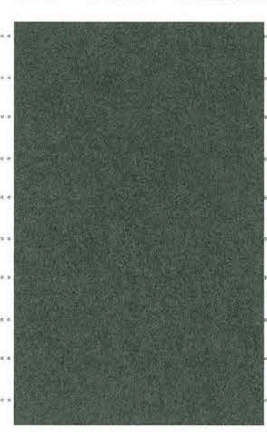

VITAMIN E
Nitric Oxide Determination

A direct comparison of the contol group and vitami E group ceptor gene caused by ascorbic acid was counteracted by the up-regulating addition of $\mathrm{I}$ - -beta estradiol.

Figure $5 \mathrm{~A}$, shows by contrast that in the alpha tocopheral (vitamin E) treatment, alpha tocopheral alone (middle lane) did not cause much change in the gene expression level of estrogen alpha-receptors when compared to the control group (first lane from left). However, the band from the combination of alpha tocopheral and r7-beta estradiol (third lane from left) is dimmer and therefore the combination of alpha tocopheral and I7-beta estradiol caused downregulation in the gene expression level of ER-alpha. It appears that alpha tocopheral and ascorbic acid have opposite effects when combined with the addition of I7-beta estradiol.

\section{NITRIC OXIDE DETERMINATION}

A total of 15 trials were performed for nitric oxide determination. Figure 6 shows the bar graph of the average amounts of NO release for three groups of MCF-7 cells with a different treatment for each group.

Overall, compared to the control group, both vitamin C and $E$ increased the level of nitric oxide release. However, it appears that vitamin $\mathrm{E}$ was more effective in boosting NO release. Figure 7 shows that this is true in a direct compari- son of the control and vitamine E. As mentioned in the introduction, an excessive amount of NO may have negative effects, but the amount of NO increased by vitamin $\mathrm{E}$ was not in a reach to be considered as an excessive level. Since NO is a scavenger for other free radicals that may promote a cancer, it appears that vitamin $\mathrm{E}$ may has positive effects in limiting cancer development by increasing NO release.

\section{FUTHER RESEARCH}

More studies regarding antioxidants and estrogen receptors will have to be done. In the future, Real Time PCR may be conducted, which is the type of PCR that gives the exact quantity of amplified cDNAs. By getting an exact quantity through conducting Real Time PCR, it would be possible to get clearer data. More trials can be conducted in addition. Also in the future, a variety of other antioxidants other than vitamin $\mathrm{C}$ and $\mathrm{E}$ will be used for similar types of experiments.

\section{CONCLUSION}

Although further studies will have to be done, this study demonstrated the overall effect of ascorbic acid (vitamin C), alpha tocopheral (vitamin E) and their combination with I7beta estradiol on ER-alpha gene expression. This study 
demonstrated that ascorbic acid might have positive effects in limiting the spread of breast cancer by decreasing the estrogen receptor level. However, this study also revealed that the combination of estrogen and ascorbic acid could cause up-regulation of ER-alpha gene expression, which may be a possible explanation for the phenomena of greater proliferation that occurred in the previous studies. It can be suspected that the combination of estrogen and ascorbic acid can make cells more vulnerable and may accelerate the MCF-7 cell growth due to the increased level of estrogen receptors.

In contrast to ascorbic acid (vitamin C), alpha tocopheral (vitamin E) caused a down-regulation of ER-alpha gene expression level when the cells were treated in combination with I7-beta estradiol. Acting alone, alpha tocopheral showed no effect on regulation of this gene.

This study also demonstrated the effect of antioxidants on the release of nitric oxide on the surface estrogen receptor of MCF-7 cells. This study showed that the both antioxidants increased NO level but vitamin $\mathrm{E}$ was more effective than vitamin $\mathrm{C}$, suggesting that vitamin $\mathrm{E}$ may have positive effects in preventing cancer. Vitamin $\mathrm{C}$ and Vitamin $\mathrm{E}$ appears to be working by different mechanisms since vitamin $\mathrm{E}$ cause a significant release of $\mathrm{NO}$, whereas vitamin $\mathrm{C}$ caused a significant decrease of ER-alpha gene expression in the MCF-7 human breast cancer cells. Overall, the data from this study will help further understand how antioxidants work in the prevention of cancers and other type of diseases.

\section{ENDNOTES}

i. Refernce I

ii. Refernce 2

iii. Refernce 2

iv. Refernce 2

v. Refernce 3

vi. Refernces 4-8

vii. Refernce 2

viii. Refernces 9-10

ix. Refernces II- I2

X. Refernces 8-I8

xi. Refernces I9-2I

xii. Refernce 22 xiii. Refernce 23

xiv. Refernces 23-27

xv. Refernces 28-3I

xvi. Refernces 32-33

xvii. Refernce 34

xviii. Refernces II-12

xix. Refernce 35

\section{REFERENCES}

I. Cheryl Cardinez, MSPH, Vilma Cokkinides, PhD, Ted Gansler, MD, Robert Greenlee, PhD, MPH, April Harris, Mary Beth Hill Harmon, MSPH, Taylor Murray, Debbie Saslow, PhD, Kim Andrew Sawyer, Joann Schellenbach, Robert Smith, PhD, Susan Summers, Dawn Willis, PhD, MPH, Harriet Zoller: Breast Cancer Facts and Figures 200r-2002 American Cancer Society, Atlanta Georgia

2. Lewis J. Kleinsmith Ph.D, Donna Kerrigan M.S., Jeanne Kelly Understanding Estrogen Receptors, Tamoxifen, and Raloxifene: Science Behind News, National Cancer Institute: http://press2.nci.nih.gov/sciencebehind/estrogen/estrogenoo.htm

3. Peter Collins \& Carolyn Webb "Estrogen hits the surface" Nature Medicine Volume 5 I999 Nature America Inc.

4. Hafner F, Holler E, von Angerer E. Effect of growth factors on estrogen receptor mediated gene expression. J Steroid Biochem Mol Biol. I996 Jul;58(4):385-93.

5. Weichselbaum RR, Hellman S, Piro AJ, Nove JJ, Little JB. Proliferation kinetics of a human breast cancer line in vitro following treatment with $r$ beta-estradiol and I-beta-D-arabinofuranosylcytosine. Cancer Res. 1978 Aug;38(8):2339-42.

6. Schor NF, Tyurina YY, Tyurin VA, Kagan VE. Differential membrane antioxidant effects of immediate and long-term estradiol treatment of MCF-7 breast cancer cells. Biochem Biophys Res Commun. I999 Jul 5;260(2):410-

7. Tesarik J, Garrigosa L, Mendoza C. Estradiol modulates breast cancer cell apoptosis: a novel nongenomic steroid action relevant 
to carcinogenesis. Steroids. I999 Jan-Feb;64(I-2):22-7

8. Perillo B, Sasso A, Abbondanza C, Palumbo G. I7beta-estradiol inhibits apoptosis in MCF-7 cells, inducing bcl-2 expression via two estrogen-responsive elements present in the coding sequence. Mol Cell Biol. 2000 Apr;20(8):2890-901.

9. Prichard RS, Hill AD, Dijkstra B, McDermott EW, O'Higgins NJ. : The prevention of breast cancer. Br J Surg. 2003 Jul; $90(7): 772-83$

IO. Wakeling AE, Newboult E, Peters SW: Effects of anioestrogens on the proliferation of MCF-7 human breast cancer cells Mol Endocrinol. 1989 May;2(3):225-34

II. Pace, P., J. Taylor, S. Suntharalingam, R. C. Coombes, and S. Ali. 1997. Human estrogen receptor binds in a manner similar to and dimerises with estrogen receptor . J. Biol. Chem. $272: 25832-25838$

I2. Shanmugam, M., N. L. Krett, E. T. Maizels, R. E. Cutler, Jr., C. A. Peters, L. M. Smith, M. L. O'Brien, O. K. Park-Sarge, S. T. Rosen, and M. Hunzicker-Dunn. I999. Regulation of protein kinase $\mathrm{C}$ delta by estrogen in the MCF-7 human breast cancer cell line. Mol. Cell. Endocrinol. I48:I09-I18

I3. Karasek M, Pawlikowski M: Antiproliferative effects of melatonin and CGP52608 Biol Signals Recept. 1999 Jan-Apr;8(I2):75-8

I4. Cos S, Mediavilla MD, Fernandez R, Gonzalez-Lamuno D, Sanchez-Barcelo EJ: Does melatonin induce apoptosis in MCF-7 human breast cancer cells in vitro? J Pineal Res. 2002 Mar;32(2):90-6

15. Blask DE, Hill SM: Effects of melatonin on cancer: studies on MCF-7 human breast cancer cells in culture. J Neural Transm Suppl. I986;21:433-49

I6. Cos S, Blask DE. Melatonin modulates growth factor activity in MCF-7 human breast cancer cells: I Pineal Res. I994
Aug;I7(I):25-32

I7. Cos S, Sanchez-Barcelo EJ: Melatonin, experimental basis for a possible application in breast cancer prevention and treatment. Histol Histopathol. 2000 Apr;15(2):637-47

18. Hill SM, Spriggs LL, Simon MA, Muraoka H, Blask DE. The growth inhibitory action of melatonin on human breast cancer cells is linked to the estrogen response system. Cancer Lett. 1992 Jul 10;6493):249-56.

I9. Crespo D, Fernandez-Viadero C, Verduga R, Ovejero V, Cos S: Interaction between melatonin and estradiol on morphological and morphometric features of MCF-7 human breast cancer cells. J Pineal Res. I994 May;16(4):215-22

20. Cos S, Sanchez-Barcelo EJ: Melatonin inhibition of MCF-7 human breast-cancer cells growth: influence of cell proliferation rate: Cancer Lett. I995 Jul 13;03(2):207-12

2I. Cos S, Recio J, Sanchez-Barcelo EJ: Modulation of the length of the cell cycle time of MCF-7 human breast cancer cells by melatonin: Life Sci. 1996;58(9):811-6

22. Tina M. Molis, Louaine L. Spriggs, Steven M. Hill: Modulation of estrogen receptor mRNA expression by melatonin in MCF-7 human breast cancer cells. Molecular Endocrinology 8:168I-1690, 1994

23. $\mathrm{Ng} \mathrm{JH}$, Nesaretnam K, Reimann K, Lai LC. Effect of retinoic acid and palm oil carotenoids on oestrone sulphatase and oestradiol-rpbeta hydroxysteroid dehydrogenase activities in MCF-7 and MDA-MB-23I breast cancer cell lines. Int J Cancer. 2000 Oct $\mathrm{I} ; 88(\mathrm{I}): 135-8$

24. Prakash P, Russell RM, Krinsky NI. In vitro inhibition of proliferation of estrogen-dependent and estrogen-independent human breast cancer cells treated with carotenoids or retinoids. J Nutr. 200I May;I3I(5):I574-80.

25. Nesaretnam K, Jin Lim E, Reimann K, Lai LC. Effect of a carotene concentrate on the growth of human breast cancer cells 
and $\mathrm{pS} 2$ gene expression. Toxicology. 2000 Oct 26;15I(I-3):Ir726.

26. Li Z, Wang Y, Mo B. [The effects of carotenoids on the proliferation of human breast cancer cell and gene expression of bcl-2] Zhonghua Yu Fang Yi Xue Za Zhi. 2002 Jul;36(4):254-7.

27. Lai LC. Role of steroid hormones and growth factors in breast cancer: Clin Chem Lab Med. 2002 Oct;40 (I0):969-74

28. Watrach AM, Milner JA, Watrach MA, Poirier KA. Inhibition of human breast cancer cells by selenium. Cancer Lett. 1984 Nov;25(I):4I-7.

29. Guthrie N, Gapor A, Chambers AF, Carroll KK. Inhibition of proliferation of estrogen receptor-negative MDA-MB-435 and positive MCF-7 human breast cancer cells by palm oil tocotrienols and tamoxifen, alone and in combination. J Nutr. I997 Mar;127(3):544S-548S

30. Malafa MP, Neitzel LT. Vitamin E succinate promotes breast cancer tumor dormancy. J Surg Res. 2000 Sep;93(I):I63-70.

31. Heisler T, Towfigh S, Simon N, McFadden DW. Peptide YY and vitamin $\mathrm{E}$ inhibit hormone-sensitive and -insensitive breast cancer cells. J Surg Res. 2000 Jun I;9I(I):9-I4.

32. Stefano GB, Cadet P, Mantione K, Cho JJ, Jones D, Zhu W. Estrogen signaling at the cell surface coupled to nitric oxide release in Mytilus edulis nervous system. Endocrinology. 2003 Apr;144(4):1234-40

33. Stefano GB, Prevot V, Beauvillain JC, Fimiani C, Welters I, Cadet P, Breton C, Pestel J, Salzet M, Bilfinger TV. Estradiol coupling to human monocyte nitric oxide release is dependent on intracellular calcium transients: evidence for an estrogen surface receptor. I Immunol. 1999 Oct 1; $16_{3}(7): 3758-63$.

34. Lirk P, Hoffmann G, Rieder J. Inducible nitric oxide synthase--time for reappraisal. Curr Drug Targets Inflamm Allergy.
$2002 \operatorname{Mar} ; \mathrm{I}(\mathrm{I}): 89-\mathrm{IO} 8$.

35. Noto V, Taper HS, Jiang YH, Janssens J, Bonte J, De Loecker W. Effects of sodium ascorbate (vitamin C) and 2-methyl-1,4naphthoquinone (vitamin $\mathrm{K}_{3}$ ) treatment on human tumor cell growth in vitro. I. Synergism of combined vitamin $\mathrm{C}$ and $\mathrm{K}_{3}$ action. Cancer. 1989 Mar 1;63(5):901-6. 